Battakhov P.P. ${ }^{\odot}$

Candidate of Law Sciences, senior research associate of the sector of enterprise and corporate law of Institute of state and law of the Russian Academy of Sciences (IGP RAS)

\title{
CONCEPT AND PROTECTION OF RUSSIAN INTELLECTUAL PROPERTY
}

\begin{abstract}
In this work, the concept of intellectual property in the Russian Federation was considered. Due to research activities in the field of IP protection, as well as the protection of these rights, it became possible to correctly disclose the relationship between these definitions. As a result, numerous regulatory and legal acts in the field of IP protection were identified, for example, International Conventions, the Constitution of the Russian Federation, and the Criminal Code of the Russian Federation. Based on the provisions of the current legislation of the Russian Federation, an analysis of the terminology of IP protection in the form of jurisdictions and non-jurisdictions was carried out.
\end{abstract}

Keywords: intellectual property, protection, contract, protection, system, convention, doctrine, civilization, means of individualization.

The phrase «intellectual property» is often spelled out in a variety of legislation, including international law. Accordingly, the term is used in domestic and foreign doctrine and practice.

Article 44, as well as 1225.2 of the Constitution of the Russian Federation, spell out provisions on intellectual property. Here, the provisions of the Constitution are duplicated, on the basis of which the regulations for the protection of IP are formed. The legal regulator of relations in the field of intellectual property is the Russian Federation.

Now many civilized countries, including the Russian Federation, are engaged in the reconstruction of culture and respect, regarding the results of any intellectual property. The Constitution and the Civil Code of the Russian Federation contain provisions that have the parameters of international agreements, as well as basic international declarations.

Intellectual property is a set of rights to specific results of intellectual activity, including individual means of legal entities, products, works performed, as well as all kinds of services that are under legal protection. Such parameters can be formed due to the creative activity of the subject, while they have an objective form.

The list of specified criteria includes:

1. Various inventions.

2. Reasonable suggestions.

3. Works of art.

4. Literary publications (including meaningful translation of the text).

5. Unique images, symbols.

6. Logos, titles and pictures that are used in the commercial sector.

7. Identification tools for organizations with a full range of works, manufactured products and services.

It is necessary to emphasize the fact that the legal regulation of this issue is included in the list of jurisdictions of the Russian Federation. The basis for legal protection is the International Regulatory Documentation, as well as the Basic Legislation of the Russian Federation. In part 2 of Art. 1225 duplicated the general theses of the situation in the field of IP protection. To fully disclose the definition in question, it is recommended to consider the meaning of each of the concepts separately (meaning «intellectual» and «property»).

\footnotetext{
(๔) Battakhov P.P., 2020
} 
The term consists of two definitions, namely "intellectual" and "property." Let's analyze each word to get an idea of the essence of the term in question.

In fact, the word "intellectual" comes from the concept of the word "intelligence." Translated from Latin, intelligence is mind or mind. Property is applicable to the results of intellectual activity. Accordingly, the property belongs to a particular person. Thus, the emphasis is placed on the prerogative of the copyright holder, in the person of whom is the person who formed some kind of product.

Intellectual property is protected by domestic and international regulations and legal acts.

In accordance with the provisions of various international conventions, the Russian Federation has the right to take part in the activities of the international arena on equal rights with other parties to agreements. Protection of IP on a rather large platform takes place in accordance with the provisions of such acts:

8. World Copyright Convention (approved in September 1952)[1];

9. Berne Convention for the Protection of Works of Art (entered into force in September 1886).

In parallel, there are various acts that apply to phonograms, copyright contracts, as well as documents to protect the activities of the industrial format. In parallel, there are other documents that perform the role of a regulator and set a certain regulation in the field of protection of the results of intellectual activity[2].

In December 2006, the fourth part began to operate in the Civil Code of the Russian Federation. The legal act made it possible to implement a solution to the problem that they had been working on for years. Now a certain order has been formed in the system of normative and legal acts that allow to ensure the regulation of relations in the field of rights to the results (objects) of intellectual activity, as well as various tools for the individualization of legal entities, products, works performed, as well as services provided.

A complete list of intellectual property objects has already been formed. The legislation protects the rights of exclusively objects, as set out in the provisions of Part 1 of Article 1225 of the Civil Code of the Russian Federation.

These objects can be divided into three categories:

10. Copyright.

11. Patent law

12. Individualization.

In Russia, the protection and protection of IP facilities can be regulated by other areas of law

These goals can be achieved in case when the direction of regulatory acts that are regulators of compliance with certain IP rights is taken into account. These restrictions are set forth in the field of public legal acts, which are listed in the Criminal Code of the Russian Federation and the Administrative Code of the Russian Federation. The subjects of study provide for the implementation of analytical measures in the field of measures aimed at the protection and responsibility of persons. These measures are set out in civil law acts.

The provisions of the first part of article 7, paragraph 12 of the Administrative Code of the Russian Federation consider administrative offenses. In accordance with the regulations of this act, it is provided for the imposition of penalties, as well as the confiscation of counterfeit IP facilities for individuals, legal entities and officials. Punishment is relevant in the case of import, distribution, illegal sale and other types of illegal sale of samples of works or phonograms in order to generate income in the future. The second part of the article was also in force. In accordance with the provisions of this act, penalties are imposed for the illegal operation of inventions, utility models or industrial designs.

It should be understood that the provisions of the Criminal Code of the Russian Federation contain articles regulating criminal liability for violation of copyright and related rights (article 146), violation of the rights to inventions and patent (article 147), as well as for the illegal use of means of individualization of products or services (article 180). 
Many rights of the Russian Federation inherited from the USSR. As a result, the Russian Federation became a full-fledged member (WIPO). The country has assumed the relevant obligations stipulated by international agreements in the field of IP protection.

Consequently, an analysis of the relationship between the concepts of "IP protection" and "IP protection" was carried out. As a result, it was possible to conclude that the first concept has more extensive content. The second definition is part of the first concept. There is a clear communication between these terms, which cannot exist separately.

The work will consider IP in detail in the Russian Federation. Research activities in the field of IP protection were implemented. As a result, it was possible to identify a whole list of the most important regulatory and legal documentation in the field of IP protection (for example, the Conventions, the Constitution of the Russian Federation, the Civil Code of the Russian Federation, the Criminal Code of the Russian Federation, the AK of the Russian Federation). Having received an idea of the current legislation of the Russian Federation, you can begin to analyze the concepts of jurisdiction and non-jurisdiction in forms of IP protection.

Analytical activities on protection and liability issues relating to IP can be carried out once the categories used in law and civil law have been identified. This refers to the regulation of relations in the event of a violation or threat of violation of a subject right of a particular person.

Protection of intellectual rights is a set of measures that allow you to restore, recognize and protect the interests of the copyright holder. In the event of violation of these rights or the formation of controversial issues, legitimate methods of regulation are used. The acts clearly regulate the forms, procedure, methods and means of protecting intellectual rights. The legislator provided many opportunities, but not all decisions in the field of ways and means of protecting intellectual rights demonstrate high efficiency in practice. The analysis of the practical exploitation of these rights helped to find out that the number of cases in the field of protection of intellectual rights in the courts of the Russian Federation is quite small, when compared with other areas of civil disputes[3].

At the same time, the total number of IP violations is steadily increasing, but many proceedings are decided in the framework of a preliminary investigation, so they do not reach the stage of a court hearing. Among the factors that provoke the development of such situations are progress in the field of research and development, improved units for copying, reliable law enforcement structures, as well as low awareness of citizens in the field of protecting the rights of copyright holders. Minimization of the level of knowledge regarding forms, methods and means of protection of IP rights is noticeable. Very few qualified specialists are involved in the protection of IP rights. Accordingly, the authors are limited in the level of consulting support, and the system of effective protection of the rights and interests of copyright holders works with certain restrictions.

Studies in the area of legal and regulatory documents have revealed the possibility of integrating jurisdictional and administrative remedies. Jurisdictional forms imply legal protection from state bodies, as well as from formations with powers in the field of legal activity. This type of protection may be exercised by the courts. There is a special procedure - administrative legal protection. Only recourse to the courts helps to ensure the implementation of the general order. Relevant cases are set out in the provisions of relevant legislation. Administrative protection provides for the use of special order. The parameters of such legal activity provide for the implementation of patent law. Therefore, there is close communication with Rospatent. In case of initiating administrative proceedings in the field of protection of secret developments, law enforcement organizations contact Rospatent and other state bodies with the relevant powers. If the violation of rights occurred as a result of activities that have signs of unfair competition, the FAS of the Russian Federation will be engaged in the protection of rights.

Any activity (or lack of activity) of Rospatent, as well as other organizations with relevant powers, can be appealed to the courts in the manner prescribed by law.

The administrative form of protection does not provide for contacting authorized formations. In general, everything happens due to the autonomous protection of rights to IP 
facilities, as well as due to the operation of legal methods of influencing the violator. In this case, the fact of activities aimed at industrial facilities falls under consideration. Understanding such issues should take into account all sorts of nuances. In general, self-defense focuses on activities within the necessary defense. This rule is spelled out in Article 1066 of the Civil Code of the Russian Federation. Issues in the field of defense in extreme necessity are regulated by the provisions of Article 1067 of the Civil Code of the Russian Federation.

Activities that become necessary due to the physical impact on the property or its owner are described above. In such a situation, activities cannot be qualified as self-protection of industrial property. Therefore, it should be noted that the independent protection of rights to an industrial property object becomes a reality through the use of a rather small range of permissible legal instruments. It is important to understand that such means cannot be universal solutions that can be used in any violation of rights. For example, self-protection of industrial property can be called the activity of the owner of rights, which is aimed at strengthening the protection of information. In parallel, the commissioning of an industrial property facility may occur.

As part of self-defense, autonomous activities can be carried out to protect violated rights. At the same time, the provisions of the current legislation in the field of necessary defense, operational measures, as well as other acts should be clearly followed. The peculiarities of the subject of study allow us to take issues in the field of non-jurisdiction regulation of protection beyond the competence of this work.

The main features of the jurisdictional protection of IP can be listed in the following form. Certain human rights have been violated. After that, the person applies to the state authorities with the appropriate competence. Based on the provisions of article 11.2 of the Civil Code of the Russian Federation, administrative legal protection of citizens is implemented in cases that are set out in the provisions of the current legislation. In part 4 of the Civil Code of the Russian Federation, on the basis of the general standards of article 11 of the Civil Code of the Russian Federation, article 1248 of the Civil Code of the Russian Federation was set out. This normative act lists the provisions in the field of judicial or administrative protection of IP rights that have been violated or challenged. The court may act as a regulator for the protection of any intellectual rights. The administrative procedure can be used in the case of implementing a certain list of communications. A general list of situations when administrative regulation can be used can be found in the provisions of Article 1248.2 of the Civil Code of the Russian Federation. Issues in the field of patent law provide for communications related to the sending and consideration of applications for the issuance of patents of the appropriate model, as well as state registration of the results of IP and the issuance of title documentation for IP. At the same time, it is permissible to consider issues regarding the challenge of IP rights, as well as the termination of the patent[5].

Autonomous legal protection can be implemented only if a specific list of requirements is met, regarding a business entity that has implemented a violation of the relevant rights of another entity, or has formed conditions for the development of this violation. The content of the stated requirements may contain preventive measures when the violator is informed that his actions are interpreted as unacceptable behavior.

Next, it should be emphasized that certain points of contention can be considered by a specialized judicial formation. The Intellectual Rights Court decides situations regarding the appeal of decisions that were taken by the organization Rospatent in resolving conflicts in an administrative manner[6].

The Intellectual Rights Court has specific competence in the field of conflict resolution, regarding intellectual rights. This formation combines the functions of the court of the first and cassation nature. This raises questions about the reasons for excluding the appellate body from the Court of Intellectual Rights. The absence of a body to appeal decisions took judicial practice beyond standard procedural procedures. It is not clear what the position of the law will be when a specialized court will be attached to the system of arbitration courts, and not to the courts of general jurisdiction. 
As a result, the analysis of the proportion of the terminology "protection of intellectual property" and "protection of intellectual rights" was successfully completed. The result of the study was the formation of the conclusion that the first definition has an extensive interpretation. The second term is part of the first and has a narrower content. Close communication was also established between the definitions considered. As a result, the conclusion was formed that these terms do not exist without each other.

\section{References:}

1.UNESCO International Regulations. M., 1993. S. 435 - 451.

2.Treaty Bulletin. 2003. N 9. S. 3 - 34.

3.Battakhov P.P. Features of the protection of rights to the results of intellectual activity//Law and state: theory and practice. 2019. № 1 (169). S. 128-132.

4.Makovsky A. On the codification of intellectual property law//Law. 2006. № 7.

5.Collection of legislation of the Russian Federation, 24.04.2006, N 17 (2 h.), Art. 1905, Rossiyskaya Gazeta, N 86, 25.04.2006.

6.Battakhov P.P. Court of the Russian Federation on Intellectual Rights//Eurasian Legal Journal. 2013. № 12 (67). C. 147-148. 